\title{
THE IMPACT OF READING SELF-MADE PERSONALISED BOOKS ON TWO- TO FOUR-YEAR-OLD CHILDREN'S LINGUISTIC EXPRESSIONS WHEN SPEAKING ABOUT THEMSELVES
}

\author{
Ona Monkevičienè, Birutė Autukevičienè, Kristina Stankevičienè \\ Vytautas Magnus University, Lithuania
}

\begin{abstract}
This study aimed to analyse the impact of reading personalised books on the linguistic expression of two-to four-year-old children when speaking spontaneously about themselves during the sensitive period of self-identification. A natural experiment was carried out using self-made books, which consisted of personalised and non-personalised parts. The personal parts of the books, which reflected each child's home environment and what they liked, were specially designed for each child. Thirty-six children aged between two and four years who attended an early childhood education institution participated in the study. The study sessions were recorded. The data analysis was conducted by applying a case study method, and the collected data were analysed qualitatively by assessing the content of the children's speech, emotions and gestures. Five typical cases were identified and described. They substantiated that the personalised parts of the books consisting of pictures from each child's environment encouraged them to use more words when speaking about themselves, to use more varied and complex means of linguistic expression when talking about familiar things, to choose appropriate linguistic means when referring to the self in the first person and/or to speak about themselves from the perspective of the other. The influence of the personalised parts of the books was not observed until the children started identifying themselves as separate subjects.
\end{abstract}

Keywords: early childhood, personalized education, linguistic expression, self-identification, personalised book

\section{Introduction}

Over the last decade, the influence of personalised education on various areas of children's education has been investigated extensively (Bray \& McClaskey, 2016; Mavrič, 2020; Pariput \& Kwangsawad, 2018; Walkington \& Bernacki, 2020). Personalised learning is defined as the maximum 
revelation of one's own potential, and it is used to customise learning content, methods and tempo and create a child-centred environment and learning aids (Lee et al., 2018; Kallick \& Zmuda, 2017). A number of researchers have studied the impact of personalised books on the education of early age children. Personalised books contain children's data such as their name, age, gender, race, appearance and preferred games, food, environment and choices (Kucirkova \& Mackey, 2020). According to Kucirkova (2018), the personalization is carried out through pictures, images, drawings, text, sound recordings.

In young children, reading personalised books leads to the stimulation of spontaneous speaking, an increase in the number of the children's utterances, the use of words and self-references, improvements in reading skills and text comprehension, motivation to read and learn new words, the location of the self and the creation of personalised stories in digital platforms and identity texts (Haiken \& Furman, 2018; Kucirkova et al., 2014b; Kucirkova, 2018; Kucirkova \& Mackey, 2020; Streelasky, 2020). Accordingly, it can be concluded that personalised books can become a mediator (a reflection of the 'self') in the process of young children's self-identification and thus encourage children to speak spontaneously about themselves. Kucirkova $(2018,3)$ argues 'Personalization offers children the opportunity to recognise themselves in the story, thus developing self-esteem and confidence'. The self is understood as a constantly evolving phenomenon, and the mediation processes in its constant formation signify a child's relationship with the surrounding world and various forms of self-representation (Audyn \& De Boer, 2020). In the process of self-identification, the child's unique relationship with the surrounding world results in the formation of self-awareness, whereas reflections of adults and the child's peers leads to the building of their social identity (Ding et al., 2019; Gardner et al., 1989). Personalised books thus become a means of reflecting the child's self. The impact of 'reading' personalised books on young children's linguistic expression in the context of self-identification and self-representation is the focus of our study.

The aim of the study was therefore to determine the impact of reading personalised books on children's linguistic expression when speaking spontaneously about themselves in the sensitive period of self-identification.

\section{Methodology}

The data were collected during a natural experiment with 36 children aged two to four years who attended an early education institution. Selfmade books consisting of personalised and non-personalised parts were designed for the experiment (suggested by Kucirkova et al., 2014a). During 
the study, which was conducted in an early childhood education institution, each child looked through or 'read' a two-part book with the researcher in a one-on-one session. On the first page of the personalised part of the book, the child saw their own photo, and other pages contained their pets and favourite toys, activities and food with or without the child's picture. The non-personalised part of the book had analogue images, but on the first page and two more pages, the child saw a picture of another child.

Four groups of children were randomly selected for the research: 2 groups each attended by eight children aged 24-36 months and 2 groups each attended by ten children aged 37-48 months. (The research was conducted during the COVID-19 pandemic, so about two thirds of children regularly attended groups of early childhood education they were assigned to). The consent regarding their children's participation in the research was received from all the parents but they themselves did not take part in the process of looking through and 'reading' books. A book was specially designed for each child who participated in the study. The information for the personalised books was collected from the child's parents using a questionnaire. They were also asked to supply a few photos of their child.

Each session was recorded. A case study method was applied, and the collected data were analysed qualitatively by assessing the content of the children's speech, emotions and gestures.

\section{Results}

The analysis of every child's case allowed grouping their cases into five groups according to similar characteristics. The cases in one group slightly differed from each other only in quantitative (but not in qualitative) characteristics, e. g., number of used words. Therefore, it is convenient to present results providing one typical case in the group with the characteristics that are observed within this particular group of children. The presented tables contain a case of a specific child with all the peculiarities of linguistic and emotional expression characteristic of this child. Children's names are changed responding to confidentiality issues.

The five cases provided below show how the children's linguistic expressions changed when they spoke about themselves during the sensitive period of self-identification. The data revealed the impact that 'reading' personalised books had on the children's linguistic expression and self-identification.

Case 1 showed that a 28-month child, Mykolas, did not identify himself ('This is ...', 'This is ...') and did not possess a sense of self (Table 1).

Words, gestures and word sentences ('This ... [points to the object]') were used not to speak about himself but only to name things and actions 
(Table 1). He named objects and actions by employing a short word, an onomatopoeic word or the beginning of a word. The personalised part of the book did not have any influence on the child's linguistic expression.

Table 1. Case 1: The Child Did Not Demonstrate Self-Awareness and Did Not Use Self-Referential Language

\begin{tabular}{|l|l|l|l|}
\hline No. & Mykolas, 28 months & Personalised & Non-personalised \\
\hline 1 & Self-identification & $\begin{array}{l}\text { Did not self-identify } \\
\text { ('This is ...', 'This is ...') }\end{array}$ & - \\
\hline 2 & $\begin{array}{l}\text { Number of first-person } \\
\text { sentences }\end{array}$ & $\begin{array}{l}\text { Gestures and word } \\
\text { sentences prevailed }\end{array}$ & $\begin{array}{l}\text { Gestures and word } \\
\text { sentences prevailed }\end{array}$ \\
\hline 3 & $\begin{array}{l}\text { Use of personal singular } \\
\text { pronouns }\end{array}$ & - & - \\
\hline 4 & $\begin{array}{l}\text { Use of personal plural } \\
\text { pronouns }\end{array}$ & - & - \\
\hline 5 & $\begin{array}{l}\text { Naming own actions using } \\
\text { verbs in the singular }\end{array}$ & Gesture and word: digs & Gesture and word: digs \\
\hline 6 & $\begin{array}{l}\text { Naming own actions using } \\
\text { verbs in the plural }\end{array}$ & - & - \\
\hline 7 & $\begin{array}{l}\text { Naming parts of own body } \\
\text { using nouns }\end{array}$ & - & - \\
\hline 8 & $\begin{array}{l}\text { Naming own clothes and } \\
\text { objects using nouns }\end{array}$ & $\begin{array}{l}\text { Naming of objects: cat, } \\
\text { tutuu [choo, choo] } \\
\text { (train), trak [tract] } \\
\text { (tractor), etc. }\end{array}$ & $\begin{array}{l}\text { Naming of objects: cat, } \\
\text { tutuu [choo, choo] } \\
\text { (train), trak [tract] } \\
\text { (tractor), etc. }\end{array}$ \\
\hline 9 & $\begin{array}{l}\text { Characterisation of self } \\
\text { and own things using } \\
\text { adjectives }\end{array}$ & - & - \\
\hline
\end{tabular}

Case 2 characterised the children who had already demonstrated self-awareness but referred to themselves in the second and third person (Table 2). In the case of Goda (27 months), emotional reaction of the girl shows that she self-identified herself. Moreover, the personalised part of the book significantly encouraged self-referential language. She used 10 third-person sentences, two second-person sentences and three first-person sentences. Personal singular pronouns ('you', 'my', 'mine') for self-identification were used six times. However, when 'reading' a non-personalised book, she only articulated one first-person sentence with 'mine'. In the personalised part of the book, Goda named her actions with the help of 12 singular verbs (vs. one verb in the non-personalised part) and used eight nouns (vs. two nouns in the non-personalised part) to refer to her things. Thus, the personalised part of the book promoted the use of self-referential language and stimulated the use of more words when speaking of herself. 
Table 2. Case 2: The Children Demonstrated Self-Awareness but Spoke Only of Themselves in the Second and Third Person

\begin{tabular}{|l|l|l|l|}
\hline No. & Goda, 27 months & Personalised & Non-personalised \\
\hline 1 & Self-identification & $\begin{array}{l}\text { Self-identified (she } \\
\text { becomes happy and says: } \\
\text { 'Goda. This is you.') }\end{array}$ & 'This is Lelia.' \\
\hline 2 & $\begin{array}{l}\text { Total number of sentences } \\
\text { (number of first-, second- } \\
\text { and third-person sentences) }\end{array}$ & $\begin{array}{l}\text { 21 (first person - 3, } \\
\text { second person - 2, third } \\
\text { person - 10) }\end{array}$ & 5 (third person - 1) \\
\hline 3 & $\begin{array}{l}\text { Use of personal singular } \\
\text { pronouns }\end{array}$ & $\begin{array}{l}\text { 6 (I - 1, you - 2, my/ } \\
\text { mine - 3) }\end{array}$ & 1 (mine - 1) \\
\hline 4 & $\begin{array}{l}\text { Use of personal plural } \\
\text { pronouns }\end{array}$ & - & - \\
\hline 5 & $\begin{array}{l}\text { Naming own actions using } \\
\text { verbs in the singular }\end{array}$ & $\begin{array}{l}12 \text { ([she] combs, sings, } \\
\text { goes, does, has etc., } \\
\text { [I] play, have, dance) }\end{array}$ & 1 (has) \\
\hline 6 & $\begin{array}{l}\text { Naming own actions using } \\
\text { verbs in the plural }\end{array}$ & - & - \\
\hline 7 & $\begin{array}{l}\text { Naming parts of own body } \\
\text { using nouns }\end{array}$ & - & - \\
\hline 8 & $\begin{array}{l}\text { Naming own clothes and } \\
\text { objects using nouns }\end{array}$ & $\begin{array}{l}8 \text { (apple, biscuits, bear, } \\
\text { umbrella, cap, mom, } \\
\text { etc.) }\end{array}$ & 2 (bear, Kakè Makè) \\
\hline 9 & $\begin{array}{l}\text { Characterisation of the } \\
\text { self and own things using } \\
\text { adjectives }\end{array}$ & - & - \\
\hline & - & \\
\hline
\end{tabular}

Case 3 characterised the children who demonstrated self-awareness, freely used self-referential language and thought and spoke about themselves from the perspective of the first person but employed only part of the analysed linguistic means (Table 3).

In the case of Šarūnas (29 months), the personalised part of the book stimulated the use of self-referential language more compared to the non-personalised part of the book. Moreover, the child was encouraged to apply adjectives to describe his own things and to actively use singular verbs to name his own actions and nouns to refer to things, clothes, people close to him, and phenomena related to him. The child's speaking was very passive when 'reading' the non-personalised part of the book. The personalised part of the book encouraged the child to speak of himself by employing more varied linguistic means and a wider vocabulary.

Case 4 described the children who with the help of language and emotions demonstrated self-awareness, employed rich self-referential language, thought and spoke about themselves from the perspective of the first person and used all the analysed linguistic means (Table 4). 
Table 3. Case 3: The Children Used Self-Referential Language but Employs Only Part of the Analysed Linguistic Means

\begin{tabular}{|l|l|l|l|}
\hline No. & Šarūnas, 29 months & Personalised & Non-personalised \\
\hline 1 & Self-identification & $\begin{array}{l}\text { Self-identified (he } \\
\text { laughs and says: } \\
\text { 'I stand') }\end{array}$ & - \\
\hline 2 & $\begin{array}{l}\text { Total number of sentences (num- } \\
\text { ber of first-person sentences) }\end{array}$ & 23 (first person - 10) & 4 (first person - 1) \\
\hline 3 & $\begin{array}{l}\text { Use of personal singular } \\
\text { pronouns }\end{array}$ & 6 (I - 3, my/mine - 3) & $2(\mathrm{I}-1, \mathrm{my}-1)$ \\
\hline 4 & Use of personal plural pronouns & - & - \\
\hline 5 & $\begin{array}{l}\text { Naming own actions using verbs } \\
\text { in the singular }\end{array}$ & $\begin{array}{l}8 \text { ([I] stand, do, don't } \\
\text { have, build, know, etc.) }\end{array}$ & - \\
\hline 6 & $\begin{array}{l}\text { Naming own actions using verbs } \\
\text { in the plural }\end{array}$ & - & - \\
\hline 7 & $\begin{array}{l}\text { Naming parts of own body using } \\
\text { nouns }\end{array}$ & - & - \\
\hline 8 & $\begin{array}{l}\text { Naming own clothes and things, } \\
\text { people and phenomena using } \\
\text { nouns }\end{array}$ & $\begin{array}{l}12 \text { (tower, ball, car, } \\
\text { festival, mom, dad, } \\
\text { puddle, water, etc.) }\end{array}$ & $\begin{array}{l}3 \text { (present, mom, } \\
\text { cars) }\end{array}$ \\
\hline 9 & $\begin{array}{l}\text { Characterisation of self and own } \\
\text { things using adjectives }\end{array}$ & 4 (such, big, these) & - \\
\hline
\end{tabular}

Table 4. Case 4: The Children Used Self-Referential Language and All the Analysed Linguistic Means

\begin{tabular}{|l|l|l|l|}
\hline No. & Eliza, 48 months & Personalised & Non-personalised \\
\hline 1 & Self-identification & $\begin{array}{l}\text { Self-identified (she gets } \\
\text { surprised: 'It's me!') }\end{array}$ & $\begin{array}{l}\text { 'I don't know this } \\
\text { doll.' }\end{array}$ \\
\hline 2 & $\begin{array}{l}\text { Total number of sentences } \\
\text { (number of first-person } \\
\text { sentences) }\end{array}$ & 33 (first person - 19) & 5 (first person - 5) \\
\hline 3 & $\begin{array}{l}\text { Use of personal singular } \\
\text { pronouns }\end{array}$ & $\begin{array}{l}17 \text { (I - 13, my/mine - } \\
4)\end{array}$ & $\begin{array}{l}5 \text { (I - 3, my/ } \\
\text { mine - 2) }\end{array}$ \\
\hline 4 & Use of personal plural pronouns & 1 (we) & - \\
\hline 5 & $\begin{array}{l}\text { Naming own actions using verbs } \\
\text { in the singular }\end{array}$ & $\begin{array}{l}17 \text { ([I] run, am, like to } \\
\text { go, go to bed, etc.) }\end{array}$ & $\begin{array}{l}3 \text { ([I] have, eat, } \\
\text { do), }\end{array}$ \\
\hline 6 & $\begin{array}{l}\text { Naming own actions using verbs } \\
\text { in the plural }\end{array}$ & 2 ([We] were, liked) & - \\
\hline 7 & $\begin{array}{l}\text { Naming parts of own body using } \\
\text { nouns }\end{array}$ & 2 (legs, head) & - \\
\hline 8 & $\begin{array}{l}\text { Naming own clothes and things, } \\
\text { people, phenomena and roles } \\
\text { using nouns }\end{array}$ & $\begin{array}{l}23 \text { (with mom, circle, I } \\
\text { am a fox) }\end{array}$ & $\begin{array}{l}3 \text { (small fish, } \\
\text { paint, small book) }\end{array}$ \\
\hline 9 & $\begin{array}{l}\text { Characterisation of self and own } \\
\text { things using adjectives }\end{array}$ & $\begin{array}{l}4 \text { ([I] nice, bare [feet], } \\
\text { wet [hair], etc.) }\end{array}$ & - \\
\hline
\end{tabular}


In the case of Eliza (48 months), the personalised part of the book stimulated her to speak about herself as a character in the book using the first person. Inspired by the personalised part of the book, she also 'read' the non-personalised part as a story about her, but her speaking in the second part was not as active as that in the first one. The personalised part of the book encouraged her to use personal singular and plural pronouns ('I', 'my', 'mine') and to identify herself with others ('we'). The application of more complex forms of present and past tense verbs to indicate her actions ('like to go', 'liked') and nouns to name the parts of her body, things, people close to her, and phenomena related to her ('circle') or her own roles ('I am a fox') was activated by personalised information. Thus, the personalised part of the book stimulated richer linguistic expressions when referring to the self and inspired her to continue speaking from a first-person perspective when 'reading' the non-personalised part of the book.

Case 5 referred to the children who demonstrated high self-awareness and were able to identify the self ('I') very well, used rich self-referential language and more complex linguistic means and spoke spontaneously about themselves while consciously switching the perspectives of the first and third person (Table 5).

In the case of Daniele (47 months), the child started creating a story with herself as the main character of the personalised part of the book. She told the story from a third-person perspective using her name but provided explanations to the researcher from a first-person perspective ('Daniele danced with the prince ... This was me and Tom dancing. I like this dress very much.'). She continued the story by 'reading' the non-personalised part of the book, but this story was shorter. The personalised part of the book encouraged the child to purposefully use personal singular and plural pronouns while switching from a first- to a third-person perspective, to choose more complex forms of verbs (the present, past and future tenses - 'I will show ...', the conditional mood - 'I would like ...') when referring to her actions from a personal perspective and the actions of the main character of the book and to use nouns when speaking about her own things and phenomena related to her ('performance', 'meeting', 'tickling') as well as adjectives to characterise herself, her things and related phenomena ('dance of joy').

Table 6 presents the data of all the 36 children related to the use of first-person sentences, words for self-characterisation and numbers while reading personalised and non-personalised parts of the book. It was convenient to use the average of sentences and words for one child as an indicator for comparison. The language of children aged 24-48 months is distinguished by significant development-predetermined and individual differences, but comparison of data of the same children on 'reading' personalised and non-personalised parts of the book allowed identifying essential differences. 
Table 5. Case 5: The Children Identified the Self 'I' Well and Consciously Switched Between the Perspectives of the First and Third Person When Speaking About Themselves

\begin{tabular}{|c|c|c|c|}
\hline No. & Danielè, 47 months & Personalised & Non-personalised \\
\hline 1 & $\begin{array}{l}\text { Self-identification and } \\
\text { naming the third person }\end{array}$ & $\begin{array}{l}\text { Self-identified (Her eyes } \\
\text { light up but she says } \\
\text { calmly: "Danielë") }\end{array}$ & $\begin{array}{l}\text { My Elžbieta (Elizabeth), } \\
\text { smiles }\end{array}$ \\
\hline 2 & $\begin{array}{l}\text { Total number of } \\
\text { sentences (number of } \\
\text { first-person sentences) }\end{array}$ & $\begin{array}{l}44 \text { (first person }-16 \text {, } \\
\text { third person }-10 \text { ) }\end{array}$ & 15 (first person -8 ) \\
\hline 3 & $\begin{array}{l}\text { Use of personal singular } \\
\text { pronouns }\end{array}$ & $5(\mathrm{I}-4, \mathrm{my} / \mathrm{mine}-1)$ & $2(\mathrm{my} / \mathrm{mine}-2)$ \\
\hline 4 & $\begin{array}{l}\text { Use of personal plural } \\
\text { pronouns }\end{array}$ & - & 1 (we) \\
\hline 5 & $\begin{array}{l}\text { Naming own actions } \\
\text { using singular verbs } \\
\text { in the present, past } \\
\text { and future tenses and } \\
\text { conditional mood }\end{array}$ & $\begin{array}{l}23 \text { ([I] was, went, [she] } \\
\text { drinks, does, [I] will } \\
\text { show, [I] would like, } \\
\text { etc.) }\end{array}$ & $\begin{array}{l}11 \text { ([I] want, [I] will be } \\
\text { happy, [I] would like, } \\
\text { etc.) }\end{array}$ \\
\hline 6 & $\begin{array}{l}\text { Naming own actions } \\
\text { using plural verbs of } \\
\text { present, past and future } \\
\text { tenses }\end{array}$ & $\begin{array}{l}5 \text { ([we] were, [we] will } \\
\text { be able, [we] have, etc.) }\end{array}$ & $\begin{array}{l}3 \text { ([we] have, [we] will } \\
\text { see) }\end{array}$ \\
\hline 7 & $\begin{array}{l}\text { Naming parts of own } \\
\text { body using nouns }\end{array}$ & - & - \\
\hline 8 & $\begin{array}{l}\text { Naming own clothes } \\
\text { and things, people and } \\
\text { phenomena using nouns }\end{array}$ & $\begin{array}{l}38 \text { (with mom, } \\
\text { performance, meeting, } \\
\text { tickling, etc.) }\end{array}$ & 15 \\
\hline 9 & $\begin{array}{l}\text { Characterisation of self } \\
\text { and own things using } \\
\text { adjectives }\end{array}$ & 9 ([dance] of joy) & 4 (such beautiful) \\
\hline
\end{tabular}

Table 6. The impact of "reading" personalised and non-personalised parts of book on children's speaking of themselves (the average of sentences and words for one child)

\begin{tabular}{|l|l|l|l|l|l|}
\hline Personalized & $\mathbf{1 0 . 0 0}$ & $\mathbf{7 . 4 1}$ & $\mathbf{1 2 . 6 6}$ & $\mathbf{1 6 . 5 0}$ & $\mathbf{3 . 0 8}$ \\
\hline Part of book & $\begin{array}{l}\text { First- person } \\
\text { sentences }\end{array}$ & $\begin{array}{l}\text { Personal } \\
\text { singular } \\
\text { pronouns }\end{array}$ & $\begin{array}{l}\text { Verbs of } \\
\text { naming own } \\
\text { action }\end{array}$ & $\begin{array}{l}\text { Nouns for } \\
\text { naming } \\
\text { parts of own } \\
\text { body and } \\
\text { things }\end{array}$ & $\begin{array}{l}\text { Adjectives } \\
\text { for naming } \\
\text { parts of own } \\
\text { body and } \\
\text { features of } \\
\text { things }\end{array}$ \\
\hline $\begin{array}{l}\text { Non- } \\
\text { personalized }\end{array}$ & 3.41 & 3.00 & 4.00 & $\mathbf{5 . 4 1}$ & $\mathbf{1 . 0 0}$ \\
\hline
\end{tabular}


The averages of the words and other linguistic means used by the children when 'reading' the personalised (P) and non-personalised (NP) parts of the book were as follows: first-person sentences $-\mathrm{P}=10.00, \mathrm{NP}=3.41$; personal singular pronouns $-\mathrm{P}=7.41, \mathrm{NP}=3.00$; verb to refer to own actions $-\mathrm{P}=12.66$, NP $=4.00$; nouns to name own parts of body, things and phenomena $-\mathrm{P}=16.50, \mathrm{NP}=5.41$; adjectives to describe qualities of own body, things and phenomena $-\mathrm{P}=3.08, \mathrm{NP}=1.00$.

Thus, reading the personalised part of the book resulted in almost three times more intensive and richer use of linguistic means when the children spoke spontaneously about themselves.

\section{Discussion and Conclusions}

Our study expands on the literature conducted by Kucirkova et al. (2014a) that analysed the linguistic means used by children in the context of self-identification. The researchers analysed children's utterances, the numbers of words used and self-references. We additionally analysed the linguistic means applied by the children in our study and distinguished between typical cases that characterised the impact of the personalised parts of the books on the children when speaking spontaneously about themselves and their use of linguistic means during the different self-identification periods.

The impact of the personalised parts of the books were not observed until the children identified the self 'I'. The personalised parts of the books encouraged clearer self-identification among the children, evoked self-referential speaking and stimulated the use of a larger number of words and more complex linguistic means. When speaking about familiar things, the children used more complex and diverse means of linguistic expression. The impact of the personalised parts of the books were not observed until the children identified themselves as separate subjects.

\section{References}

Audyn, C., \& De Boer, B. (2020). Brain imaging technologies as source for extrospection: Self-formation through critical self-identification. Phenomenology and the Cognitive Sciences, 19, 729-745. https://doi.org/10.1007/s11097-020-09667-1

Bray, B., \& McClaskey, K. (2016). How to Personalize Learning. California, Sage Publishing.

Ding, X. P., O'Connor, A. M., Weng, M., Tang, Q., Fu, G., \& Evans, A. D. (2019). The effects of self- and other-awareness on Chinese children's truth-telling. British Journal of Developmental Psychology, 37, 323-335. https://doi:10.1111/bjdp.12275

Gardner, R., Gallegos, V., Martinez, R., \& Espinoza, T. (1989). Mirror feedback and judgments of body size. Journal of Psychosomatic Research, 33(5), 603-607. https:// doi:10.1016/0022-3999(89)90067-6 
Haiken, M., \& Furman, R. (2018). Personalized reading: Digital strategies and tools to support all learners. International Society for Technology in Education.

Lee, D., Huh, Y., Lin, C.-Y., \& Reigeluth, C. M. (2018). Technology functions for personalized learning in learner entered schools. Educational Technology Research and Development, 66, 1269-1302. https://doi.org/10.1007/s11423-018-9615-9

Kallick, B., \& Zmuda, A. (2017). Students at the center: Personalized learning with habits of mind. ASCD.

Kucirkova, N. (2018). A taxonomy and research framework for personalization in children's literacy apps. Educational Media International, 55(3), 255-272. https://doi.org/ 10.1080/09523987.2018.1512446

Kucirkova, N., \& Mackey, M. (2020). Digital literacies and children's personalized books: Locating the 'self'. London Review of Education, 18(2), 151-162. https://doi.org/ 10.14324/LRE.18.2.01

Kucirkova, N., Messer, D., \& Sheehy, K. (2014a). The effects of personalisation on young children's spontaneous speech during shared book reading. Journal of Pragmatics, 71, 45-55. http://dx.doi.org/10.1016/j.pragma.2014.07.007

Kucirkova, N., Messer, D., \& Sheehy, K. (2014b). Reading personalised books with preschool children enhances their word acquisition. First Language, 34(3), 227-243. https://doi.org/10.1177/0142723714534221

Mavrič, M. (2020). The Montessori Approach as a Model of Personalized Instruction. Journal of Montessori Research, 6(2), 13-25.

Pariput, P., \& Kwangsawad, T. (2018). The effect of play-based personalized learning model on students' expert learning. Journal of Community Development Research, 11(2), 62-69.

Streelasky, J. (2020). Creating identity texts with young children across culturally and linguistically diverse contexts. Journal of Early Childhood Research, 18(3), 243-258. http://dx.doi.org.ezproxy.vdu.lt/10.1177/1476718X19898715

Walkington, C., \& Bernacki, M. L. (2020). Appraising research on personalized learning: Definitions, theoretical alignment, advancements, and future directions. Journal of Research on Technology in Education, 52(3), 235-252. https://doi.org/10.1080/1539152 3.2020 .1747757 